Vol. 5 (1996): 529-534.

\title{
A mouse model for improving cell survival of bisected cattle embryos
}

\author{
Peter Bredbacka' \\ Agricultural Research Centre of Finland, Institute of Animal Production, Finland
}

\begin{abstract}
Morula and blastocyst stage embryos recovered from B6D2F, mice were bisected with a metal microblade in M2 medium with or without sucrose and/or cytochalasin B supplementation. Cell lysis was determined by staining the embryos with Hoechst 33258 and propidium iodide. Lysed cells take up both stains but non-lysed cells only the Hoechst 33258 stain, resulting in pink fluorescence for lysed cells and blue fluorescence for non-lysed cells under UV excitation. During bisection of morulae, the presence of cytochalasin $\mathrm{B}$ decreased the proportion of lysed cells in both the absence $(\mathrm{P}=0.0001)$ and presence of sucrose $(\mathrm{P}=0.001)$. During bisection of blastocysts the average proportion of lysed cells was slightly lower in the presence of cytochalasin than that in the control medium, but the effect was not statistically significant $(\mathrm{P}=0.34)$. No effect of sucrose was observed in either demi-morulae or demi-blastocysts. These results are essentially similar to those obtained in simultaneous experiments with cattle embryos, suggesting that the simpler mouse model might be useful for developing less traumatic bisection protocols for cattle embryos.
\end{abstract}

Key words: demi-embryo, splitting, cell lysis, propidium iodide, Hoechst 33258 , cytochalasin, sucrose

'Present address: Finnish Animal Breeding Association, P.O. Box 40, FIN-01301 Vantaa, Finland, e-mail: peter.bredbacka@mloy.fi

\section{Introduction}

Embryo bisection can be used in embryo transfer programmes either to increase the number of transferable (demi)embryos or to produce identical twin calves for research or other purposes. The first successful transfers of bisected bovine embryos were reported in the early 1980s (Willadsen et al. 1981, Ozil et al. 1982).
Although embryo bisection yields more offspring per original embryo under appropriate conditions, subsequent splitting of an embryo does not seem to give any further benefit, as the viability of quarter embryos is roughly half that of demi-embryos (Willadsen et al. 1981, Bredbacka et al. 1992). Demi-embryos apparently are particularly sensitive to further invasive treatments. Substantial cell loss in bisected embryos will either compromise further development before implantation 


\section{AGRICULTURAL AND FOOD SCIENCE IN FINLAND}

Bredbacka, P. Cell lysis in demi-embryos

or result in an insufficient embryonic signal for maternal recognition, or both.

The success of producing live foetuses after splitting varies, depending upon factors such as bisection technique (Mertes and Bondioli 1985), embryo age and stage (Williams et al. 1984, McEvoy and Sreenan 1990), method of transfer (Takeda et al. 1986), and type and status of recipient (Arave et al. 1987, Bredbacka et al. 1992). However, data on the survival of cells during bisection are sparse, as are the published data on attempts to increase viability of blastomeres during the splitting process. A recent report (Bredbacka 1995) demonstrates that a considerable proportion (about $20 \%$ to $30 \%$ ) of blastomeres lyses in embryos bisected using a microblade-assisted technique. The effectiveness of the technique is nevertheless confirmed by a $60 \%$ pregnancy rate of demi-embryos transferred singly (Bredbacka et al. 1996). Survival after serial splitting might be significantly improved, if cell lysis could be prevented more efficiently.

The major factor holding up improvements to bovine embryo bisection protocols is the cost of embryos. Although in vitro produced (IVP) embryos represent a relatively inexpensive alternative to in vivo produced embryos, the IVP technology is more elaborate and requires embryo culture facilities. Furthermore, regardless of the method of embryo production, bovine embryos exhibit a large variation in morphology, which sometimes complicates interpretation of results.

The aim of my study was to demonstrate the feasibility of a mouse model for predicting cell survival in bovine embryos. The effect of sucrose and cytochalasin B on cell survival was investigated with differential staining of lysed and nonlysed cells. The results were compared with those of a parallel study in the bovine (Bredbacka 1995).

\section{Material and methods}

Female B6D2F $\left(\right.$ C57BL6 x DBA $\left.F_{1}\right)$ mice were first superovulated by injecting 5 to $7.5 \mathrm{IU}$
PMSG and 5 IU hCG $48 \mathrm{~h}$ apart and then mated with B6D2F, males. Compacted morulae were recovered 73 to 75 hours after the hCG injection and blastocysts were recovered 90 to $94 \mathrm{~h}$ after the hCG injection using the method devised by Hogan et al. (1986).

The nuclei of blastomeres were stained by exposing the embryos to $20 \mu \mathrm{g} / \mathrm{ml}$ Hoechst 33258 stain in 4-well Nunc dishes (Nunc, Cat No. 176740, Roskilde, Denmark) for 3 to $5 \mathrm{~h}$ at $37 \% \mathrm{C}$ in air. The stain was diluted in $500 \mu \mathrm{l}$ of M2 medium (Quinn et al. 1982) containing $4 \mathrm{mg} / \mathrm{ml}$ bovine serum albumin (M2+BSA). The M2 was made up of analysis grade chemicals and the BSA was from Sigma (Cat. No. A-9647, St. Louis, MO, USA). Each embryo was evaluated immediately before splitting using a Leitz Fluovert inverted microscope; embryos with any indication of abnormal morphology were excluded from the experiments.

The control medium for bisection was M2+BSA. In the treatment groups the sucrose was added at a concentration of $200 \mathrm{mM}$, and cytochalasin B (Sigma, Cat. No. C6762, St. Louis, MO, USA) was used at $7.5 \mu \mathrm{g} / \mathrm{ml}$. The combination of cytochalasin $\mathrm{B}$ and sucrose was also tested in the experiments with morulae. Before being split in sucrose-containing medium, the embryos were allowed to equilibrate for 3 to 5 min in the medium at room temperature. When bisected in the presence of cytochalasin B, the embryos had an equilibration time of 5 to $15 \mathrm{~min}$ at room temperature.

The embryos were bisected with a Leitz micromanipulator using a microblade prepared from a razor blade (Williams and Moore 1988) and the "scratched bottom technique" (Bredbacka 1991). With this technique, scratches are produced parallel to the orientation of the microblade on the bottom of the lid of a plastic petri dish (Nunc, Cat. No. 153066, Roskilde, Denmark) to prevent the embryo from slipping during bisection. The embryo is then bisected by a vertical movement of the microblade in a drop of 100-200 $\mu \mathrm{l}$ of medium. Blastocysts are bisected so that both the trophectoderm and inner cell mass are halved. To reduce the stickiness of 
Vol. 5 (1996): 529-534.

Fig. 1. Brightfield and fluorescence image of a mouse demi-morula. Pink fluorescence indicates staining of nuclei of lysed cells and blue fluorescence staining of nuclei with intact cells. (Photos: Peter Bredbacka).
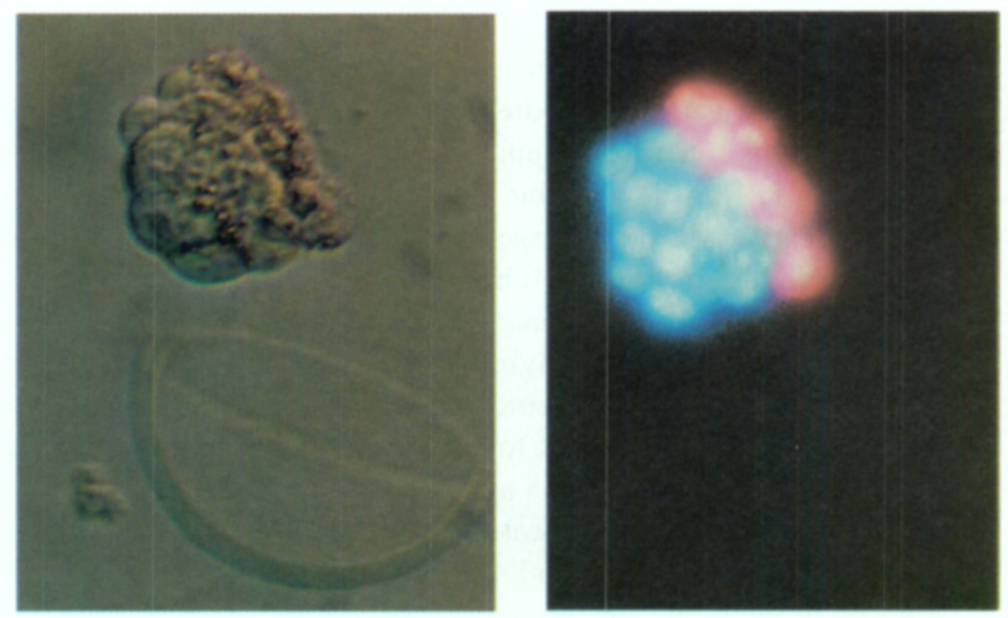

blastomeres the stage was chilled to about 10 $15^{\circ} \mathrm{C}$ by placing precooled aluminium blocks on the Leitz Fluovert microscope stage. The temperature of the stage was monitored by a Linkam CO60 stage warmer with the heating off.

After the splitting, each demi-embryo pair was placed in a $50 \mu \mathrm{l}$-drop of M2+BSA. Propidium iodide (Sigma, Cat. No. P-4170, St. Louis, MO, USA) was added to a final concentration of $10 \mu \mathrm{g} / \mathrm{ml}$ to stain nuclei of lysed cells. After 45 to $60 \mathrm{~min}$ of staining at room temperature, each demi-embryo pair was washed and placed into $50 \mu \mathrm{l}$ of medium in a well of a 96-well plastic dish. The nuclei were counted by fluorescence microscopy using a Leitz Fluovert microscope with filter block $\mathrm{A}$.

Cells of each embryo were classified as lysed (pink fluorescence) or viable (blue fluorescence), with the results being expressed as the proportion of the total number of cells. Data were analysed by variance analysis using the Statistical Analysis System (SAS Institute, Cary, NC, USA).

\section{Results}

The average number of nuclei ( \pm SEM) in morulae was $18.5( \pm 0.6)$ and in blastocysts 47.3
Table 1. Cell viability of mouse morulae after splitting in different media.

\begin{tabular}{lccc}
\hline Treatment & $\mathrm{n}$ & $\begin{array}{c}\text { Proportion }( \pm \text { SEM) } \\
\text { of viable cells }\end{array}$ & P value $^{\mathrm{a}}$ \\
\hline Control & 24 & $0.41( \pm 0.03)$ & - \\
Cytochalasin B & 24 & $0.56( \pm 0.02)$ & 0.0001 \\
$\begin{array}{l}\text { Sucrose } \\
\text { Cytochalasin B }\end{array}$ & 24 & $0.43( \pm 0.02)$ & 0.52 \\
$\quad$ & & & \\
$\quad+$ sucrose & 24 & $0.55( \pm 0.03)$ & 0.0001 \\
\hline
\end{tabular}

a In comparison with control medium

Table 2. Cell viability of mouse blastocysts after splitting in the presence of cytochalasin B.

\begin{tabular}{lccc}
\hline Treatment & $\mathrm{n}$ & $\begin{array}{c}\text { Proportion }( \pm \text { SEM) } \\
\text { of viable cells }\end{array}$ & P value $^{\mathrm{a}}$ \\
\hline Control & 19 & $0.47( \pm 0.02)$ & - \\
Cytochalasin B & 20 & $0.49( \pm 0.02)$ & 0.34 \\
\hline
\end{tabular}

a In comparison with control medium

Table 3. Cell viability of mouse blastocysts after splitting in the presence of sucrose.

\begin{tabular}{lccc}
\hline Treatment & $\mathrm{n}$ & $\begin{array}{c}\text { Proportion }( \pm \text { SEM) } \\
\text { of viable cells }\end{array}$ & P value $^{a}$ \\
\hline Control & 20 & $0.45( \pm 0.02)$ & - \\
Sucrose & 20 & $0.45( \pm 0.02)$ & 0.96 \\
\hline
\end{tabular}

a In comparison with control medium. 


\section{AGRICULTURAL AND FOOD SCIENCE IN FINLAND}

Bredbacka, P. Cell lysis in demi-embryos

$( \pm 0.9)$. After the staining, the nuclei of most blastomeres along the plane of the bisection embryos typically displayed pink fluorescence as an indication of propidium iodide uptake, whereas the remaining nuclei showed blue fluorescence (see Fig. 1). The results of the bisection of morulae are summarized in Table 1. When compared with bisection in control medium, an increase in the proportion of viable (non-lysed) cells was found in media supplemented with cytochalasin B, whereas no such effect was found with the addition of sucrose. Cytochalasin also decreased cell lysis in the presence of sucrose $(\mathrm{P}=0.001)$.

Table 2 summarizes the results of bisecting blastocysts in medium containing cytochalasin B. The effect of the addition of sucrose on cell survival during bisection of blastocysts is summarized in Table 3. No beneficial effects of the treatments on cell viability in blastocysts were observed.

\section{Discussion}

Using the same method as in this study a previous investigation demonstrated that about a quarter of the cells in Day 7 cattle embryos (about $20 \%$ in morulae, $25-30 \%$ in blastocysts) lyse when bisected with a metal blade (Bredbacka $1995)$. The present study suggests that the proportion of lysed cells in bisected mouse embryos is even higher than in cattle embryos. About half of the blastomeres expressed membrane rupture as indicated by uptake of propidium iodide. One possible explanation for this difference is the lower cell numbers in mouse morulae and blastocysts: in the previous experiment (Bredbacka 1995) cattle morulae had 2-4 times as many nuclei and cattle blastocysts about twice as many nuclei as the corresponding developmental stages of mouse embryos in this study. Consequently, in the mouse, a higher proportion of cells would be located in the plane of bisection. It is also possible that mouse blastomeres are more sensitive to damage from bisection.
Cytochalasins inhibit reversibly the polymerization of actin, thus enhancing the flexibility of cell membranes. This property has been used to decrease cell damage in nucleus transfer experiments (for review, see Loskutoff 1990). Cytochalasin B has been shown to decrease cell lysis during bisection of Day 7 bovine embryos (Bredbacka 1995). In the present study, treatment of mouse morulae with cytochalasin B significantly decreased the proportion of lysed cells in bisected morulae. Note that a highly significant difference $(\mathrm{P}=0.0001)$ from the control medium could be shown with only a small number of embryos (24 per treatment).

Despite the clearly beneficial effect of cytochalasin B in morulae, no clear effect of this compound was demonstrated in blastocysts. Since the proportion of non-lysed cells was slightly higher in the presence of cytochalasin, it is possible that the number of embryos was too low to demonstrate an actual effect. On the other hand, cytochalasin may provide less protection for cells in blastocysts. It is also possible that the inner cell mass (ICM) and the trophectoderm (TE) respond differently to cytochalasin. If cytochalasin protects only one of the two cell types, variation in the ICM/TE ratio between embryos would mask the actual effects. This stresses the need to use more embryos for analysis unless cell survival can be measured separately in the ICM and TE.

It has been proposed, that adding of sucrose to the splitting medium inhibits pressure-induced cell membrane rupture during the splitting process by means of dehydration (Herr et al. 1988). In the present study the addition of sucrose at a concentration of $200 \mathrm{mM}$ had no beneficial effect on mouse blastomere survival. The same conclusion was drawn in the study with bovine embryos (Bredbacka 1995). Addition of sucrose at another concentration, however, might have rendered the blastomeres more resistant to the stress induced by the bisection procedure.

The observations made here with mouse morulae are essentially identical to the results obtained with cattle embryos (Bredbacka 1995), suggesting that mouse embryos might be useful 
Vol. 5 (1996): 529-534.

for developing splitting techniques in cattle. In an experiment with a limited number of equine embryos, cytochalasin B tended to protect cell lysis (Huhtinen et al. 1995), implying the possibility of using the mouse model across several species.

Bringing cell lysis down to a minimum could improve the efficiency of embryo transfer programmes not only by making bisection less traumatic, but also by improving biopsy for preimplantation diagnosis. Increased cell viability of biopsied embryos could have a substantial effect on pregnancy rates when biopsy is combined with cryopreservation.

The use of mouse embryo bisection as a model for improving the cattle embryo splitting protocol has several advantages. The cost of producing mouse embryos is reasonable especially compared with in vivo produced cattle embryos. Although the use of the latter need not be ruled out, mouse embryos show less variability in qual- ity as assessed by morphological criteria, not least because inbred lines or hybrid $\mathrm{F}_{1}$ lines can be used. The dead cells often present in intact cattle embryos complicate splitting experiments, as lysed cells take up propidium iodide even without the cell injury induced by microsurgery and so have to be excluded from analysis. Last, but not least, with about half of the cells lysing in a standard splitting protocol with mouse embryos, improvements to the protocol are easier to measure than with cattle embryos, in which roughly $25 \%$ of the cells lyse in the standard protocol.

In conclusion, the use of mouse embryos offers a valuable tool for selecting protocols for further bisection and biopsy studies with cattle embryos.

Acknowledgements. I thank T.-M. Nieminen for management of the mice and preparation of the media used in this study and $\mathrm{K}$. Bredbacka for useful suggestions with regard to the manuscript.

\section{References}

Arave, C.W., Bunch, T.D., Mickelsen, C.H. \& Warnick, K. 1987. Factors affecting survivability of transferred whole and demi-embryos in a commercial dairy herd. Theriogenology 28: 373-382.

Bredbacka, P. 1991. Biopsy of morulae and blastocysts. Reproduction in Domestic Animals 26: 82-84.

- 1995. Factors affecting cell viability during bisection of bovine embryos. Theriogenology 44: 159-166.

-, Huhtinen, M., Aalto, J. \& Rainio, V. 1992. Viability of bovine demi- and quarter-embryos after transfer. Theriogenology 38: 107-113.

-, Jaakma, Ũ. \& Müürsepp, I. 1996. Production of calves following nonsurgical transfer of fresh and refrigerated bovine demi-embryos. Agricultural and Food Science in Finland 5: 521-527.

Herr, C., Holt, N. \& Reed, K.C. 1988. Effect of sucrose and calcium in the splitting medium on survival of quartered ovine morulae. Proceedings of the Annual Conference of the Australian Society of Reproductive Biology. 20: 10. (Abstract).

Hogan, B., Constantini, F. \& Lacy, E. 1986. Manipulating the Mouse Embryo: A Laboratory Manual. New York: Cold Spring Harbor Laboratory. p. 92-95.

Huhtinen, M., Bredbacka, P. \& Kotilainen, T. 1995. Nonsurgical transfer of DAPI-stained equine demi-embryos treated with cytochalasin B and nocodazole. Biology of Reproduction, Monograph Series No. 1: 325-328.

Loskutoff, N.M. 1990. Micromanipulation of embryos and gametes. Embryo Transfer Newsletter 8: 5-14.
McEvoy, T.G. \& Sreenan, J.M. 1990. Effect of embryo quality and stage of development on the survival of zona pellucida-free cattle demi-embryos. Theriogenology 33 : 1245-1253.

Mertes, P.C. \& Bondioli, K.R. 1985. Effect of splitting technique on pregnancy rate from half embryos. Theriogenology 23: 209. (Abstract).

Ozil, J.P., Heyman, Y. \& Renard J.P. 1982. Production of monozygotic twins by micromanipulation and cervical transfer in the cow. Veterinary Record 110: 126-127.

Quinn, P., Barros, C. \& Whittingham, D.G. 1982. Preservation of hamster oocytes to assay the fertilizating capacity of human sperm. Journal of Reproduction and Fertility 66: 161-168.

Takeda, T., Hallowell, S.V., McCauley, A.D. \& Hasler, J.F. 1986. Pregnancy rates with intact and split embryos transferred surgically and nonsurgically. Theriogenology 25: 204. (Abstract).

Willadsen, S.M., Lehn-Jensen, H., Fehilly, C.B. \& Newcomb, R. 1981. The production of monozygotic twins of preselected parentage by micromanipulation of non-surgically collected cow embryos. Theriogenology 15: 2329.

Williams, T.J., Elsden, R.P. \& Seidel, G.E., Jr. 1984. Pregnancy rates with bisected bovine embryos. Theriogenology 22: 521-531.

- \& Moore, L. 1988. Quick-splitting of bovine embryos. Theriogenology 29: 477-484. 


\title{
SELOSTUS
}

\section{Hiiren alkio mallina solukestäryyden parantamiseksi naudan alkioiden halkaisussa}

\author{
Peter Bredbacka \\ Maatalouden tutkimuskeskus
}

Morula- ja blastokystivaiheessa olevia hiiren alkioita halkaistiin mikroterällä M2-liuoksessa. Halkaisukokeessa tutkittiin sakkaroosin $(200 \mathrm{mM})$ ja sytokalasiinin $(7,5 \mathrm{ug} / \mathrm{ml})$ vaikutusta solujen kestävyyteen kaksoisvärjäyksen avulla. Värjäyksen jälkeen solut voidaan erottaa toisistaan fluoresenssimikroskoopin avulla värin perusteella. Hoechst 33258-väri värjää kaikki solut (sininen fluoresenssi), ja propidiumjodi vain tuhoutuneet solut (vaaleanpunainen fluoresenssi).

Morulavaiheessa olevia alkioita halkaistaessa sytokalasiini vähensi hajonneiden solujen osuutta riip- pumatta siitä, oliko liuoksessa myös sakkaroosia. Kun käytettiin blastokystivaiheessa olevia alkioita, eri käsittelyillä ei havaittu vaikutusta hajonneiden solujen määriin. Sakkaroosilla ei ollut vaikutusta blastokystivaiheen solujen kestävyyteen. Nämä tulokset ovat samansuuntaisia kuin vastaavasta naudan alkioilla tehdystä kokeesta saadut tulokset. Halkaisussa tuhoutuneiden solujen erottaminen on hiiren alkiolla helpompaa kuin naudan alkioilla. Edullisena ja yksinkertaisena hiirimalli voi olla hyödyllinen kehitettäessä naudan alkion soluja paremmin suojaavia mikrokirurgisia menetelmiä. 